\title{
Stereospecific Hydrogen Transfer from C-4 to C-6 during Enzymatic Transformation of Cholesterol into Cholestenone ${ }^{1)}$
}

\author{
Toshio Nambara, Shigeo Ikegawa, Toshiko Hirayama, \\ and Hiroshi Hosoda \\ Pharmaceutical Institute, Tohoku University ${ }^{2}$
}

(Received July 20, 1977)

\begin{abstract}
In order to clarify the steric mechanism for biotransformation of $\Delta^{5}-3 \beta$-hydroxysteroid into $\Delta^{4}-3$-ketosteroid the metabolic fate of hydrogen at C-4 during conversion of cholesterol into cholestenone by $3 \beta$-hydroxysteroid oxidase has been investigated. Of three substrates required for this purpose $4 \alpha-d_{1}$-cholesterol was prepared through $4-d_{1^{-}}$ cholest-4-en-3 $\beta$-ol tert-butyldimethylsilyl ether as a key intermediate. The substrate was incubated with the enzyme, and the content and locality of deuterium in resulting cholestenone were determined by inspection of the mass, nuclear magnetic resonance, and infrared spectra. The transformation products formed from $4 \alpha$ - and 6 - deuterated cholesterols retained the label almost intact, while that derived from $4 \beta$ - $d_{1}$-cholesterol showed $c a .50 \%$ retention of the heavy isotope at $6 \beta$. Incubation studies using $6 \beta$ - $d_{1}$-cholestenone as a substrate implied that a $50 \%$ loss of the label would be ascribable in part to the exchange with the incubation medium under the enzymatic control. These results led to a definite conclusion that $4 \beta$-hydrogen was transferred stereospecifically to the $6 \beta$ position during biotransformation of cholesterol into cholestenone.
\end{abstract}

Keywords-3 - $3 \beta$-hydroxysteroid oxidase; $\Delta^{5} \rightarrow \Delta^{4}$ isomerization; steric mechanism; stereospecific labeling; lithium aluminum deuteride; $4 \beta$ - $d_{1}$-cholesterol; $4 \alpha$ - $d_{1}$-cholesterol; $6 \beta$ - $d_{1}$-cholestenone; deuterium retention; hydrogen exchange

The microbial transformation of $\Delta^{5}$-3 3 -hydroxysteroid into $\Delta^{4}$-3-ketosteroid is of particular interest in connection with the biosynthesis of steroid hormones in the living animals. The steric mechanism for the migration of the double bond has been extensively investigated with several enzyme systems. ${ }^{3-9)}$ Ringold and his co-worker have previously demonstrated that during the isomerization of androst-5-ene-3,17-dione into androst-4-ene-3,17-dione by $\Delta^{5}$-3-ketosteroid isomerase from Pseudomonas testosteroni $4 \beta$-hydrogen is transferred to the $6 \beta$-position. ${ }^{10)}$ This explanation, however, is not fully acceptable because the only $4 \beta$-deuterated substrate was used for the incubation study. As a series of our studies on the microbial transformation of steroids, ${ }^{11)}$ elucidation of the steric mechasinm for the hydrogen transfer from C- 4 to C-6 during conversion of cholesterol (cholest-5-en-3 $\beta$-ol) into cholestenone (cholest-

1) Part CXXX of "Studies on Steroids" by T. Nambara; Part CXXIX: T. Nambara, J. Goto, H. Furuyama, and H. Kato, Chem. Pharm. Bull. (Tokyo), 26, 632 (1978).

2) Location: Aobayama, Sendai, 980, Japan.

3) H. Werbin and I.L. Chaikoff, Biochim. Biophys. Acta, 82, 581 (1964).

4) M.G. Ward and L.L. Engel, J. Biol. Chem., 239, PC3604 (1964); idem, ibid., 241, 3147 (1966).

5) J.M. Rosner, P.F. Hall, and K.B. Eik-Nes, Steroids, 5, 199 (1965).

6) N.L. Oleinick and S.B. Koritz, Biochemistry, 5, 3400 (1966).

7) H.L. Bradlow, D.K. Fukushima, B. Zumoff, and L. Hellman, Steroids, 11, 273 (1968); D.K. Fukushima, H.L. Bradlow, T. Yamauchi, A. Yagi, and D. Koerner, ibid., 11, 541 (1968).

8) C.J. Sih and H.W. Whitlock, Jr., Annu. Rev. Biochem., 37, 682 (1968).

9) F.F. Knapp, L.J. Goad, and T.W. Goodwin, Chem. Commun., 1973, 143; J.S. William, R.B. Lockley, J.L-J. Gareth, H.H. Rees, and T.W. Goodwin, ibid., 1975, 346.

10) S.K. Malhotra and H.J. Ringold, J. Am. Chem. Soc., 87, 3228 (1965).

11) T. Anjyo, M. Ito, H. Hosoda, and T. Nambara, Chem. Ind. (London), 1972, 384; S. Ikegawa and T. Nambara, ibid., 1973, 230; T. Nambara, T. Anjyo, M. Ito; and H. Hosoda, Chem. Pharm. Bull. (Tokyo), 21, 1938 (1973); T. Nambara, S. Ikegawa, and H. Hosoda, ibid., 21, 2794 (1973); T. Nambara, S. Ikegawa, and M. Kato, ibid., 23, 2164 (1975); T. Nambara, S. Ikegawa, and C. Takahashi, ibid., 23, 2358 (1975). 
4-en-3-one) by $3 \beta$-hydroxysteroid oxidase [E.C. 1.1.3.6], derivable from Brevibacterium sterolicum, ${ }^{12)}$ has been undertaken.

Of the substrates required for this purpose, $4 \beta-d_{1}$-cholesterol $(\mathbf{1 b})$ was prepared by the route previously established in these laboratories, ${ }^{13)}$ and $6-d_{1}$-cholesterol (1c) was obtained from $6-d_{1}$-cholest-5-en- $3 \beta$-ol acetate ${ }^{14)}$ by alkaline hydrolysis under the mild conditions. The remaining substrate, $4 \alpha-d_{1}$-cholesterol (1a), was conveniently synthesized as shown in Chart 1 .

An initial effort was directed to the preparation of 4 - $d_{1}$-cholest- 4 -en-3 $3 \beta$-ol tert-butyldimethylsilyl ether as a key intermediate. Hydroboration of cholest-4-en-3 $\beta$-ol tert-butyldimethylsilyl ether (2a) and subsequent oxidation of the organoborane with alkaline hydrogen peroxide provided solely a cis-addition product, $5 \alpha$-cholestane-3 $\beta, 4 \alpha$-diol 3 -monosilyl ether $(3 \mathrm{~b})$. The configurational assignment of the cis-adduct was justified by leading to the known $3 \beta, 4 \alpha$-diol (3a) by acid hydrolysis. Being treated with pyridinium chlorochromate, $3 \mathbf{b}$ underwent oxidation to yield the 4-ketone (4) as a single product. It is sufficiently substantiated

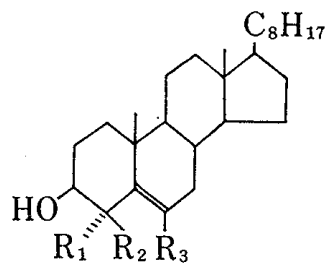

$$
\begin{aligned}
1 \mathbf{a}: & \mathrm{R}_{1}=\mathrm{D}, \mathrm{R}_{2}=\mathrm{R}_{3}=\mathrm{H} \\
\mathbf{b}: & \mathrm{R}_{2}=\mathrm{D}, \mathrm{R}_{1}=\mathrm{R}_{3}=\mathrm{H} \\
\mathbf{c}: & \mathrm{R}_{3}=\mathrm{D}, \mathrm{R}_{1}=\mathrm{R}_{2}=\mathrm{H}
\end{aligned}
$$

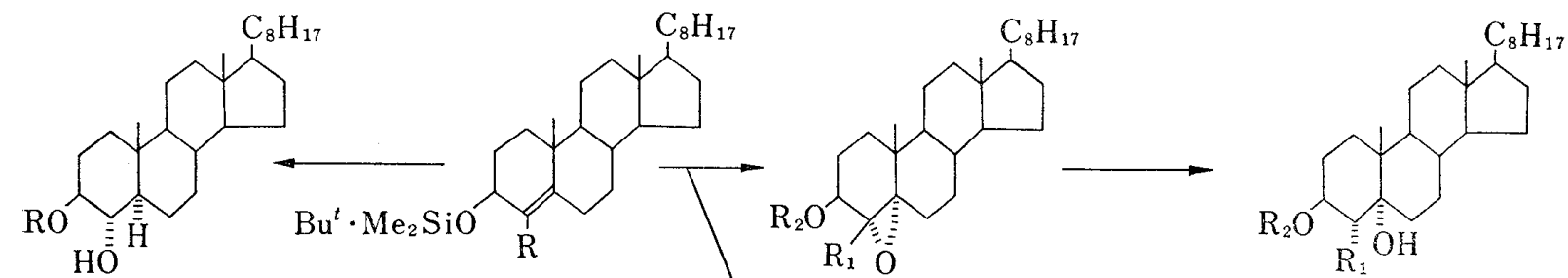

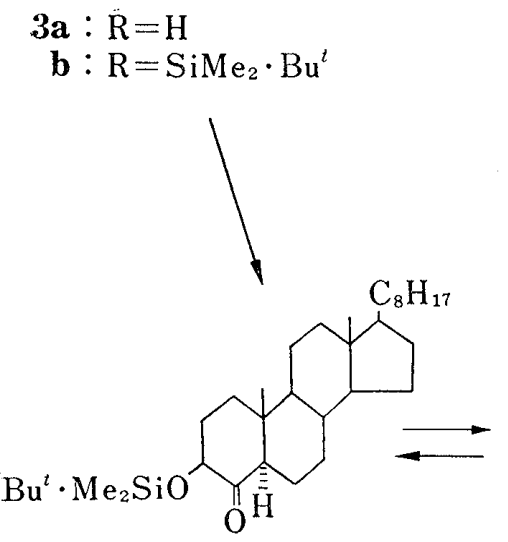

$$
\begin{aligned}
\mathbf{2 a}: & \mathrm{R}=\mathrm{H} \\
\mathbf{b}: \mathrm{R} & =\mathrm{D}
\end{aligned}
$$

$6 \mathbf{a}: \mathrm{R}_{1}=\mathrm{R}_{2}=\mathrm{H}$

b : $\mathrm{R}_{1}=\mathrm{H}$, $\mathrm{R}_{2}=\mathrm{SiMe}_{2} \cdot \mathrm{Bu}^{t}$ $c: R_{1}=D$,

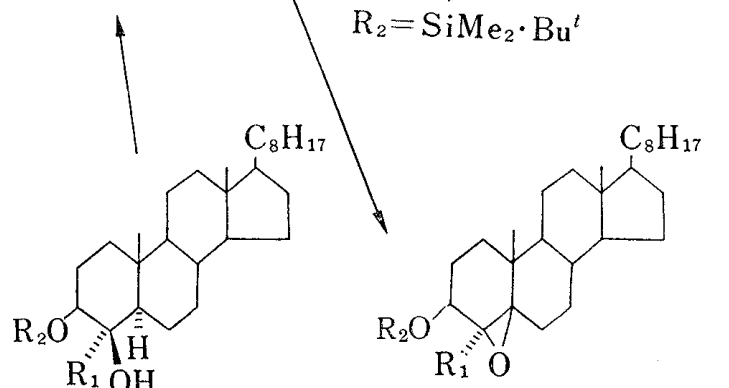
$\mathrm{R}_{1} \mathrm{OH}$

$$
\begin{aligned}
5 \mathbf{a}: & \mathrm{R}_{1}=\mathrm{R}_{2}=\mathrm{H} \\
\mathbf{b}: & \mathrm{R}_{1}=\mathrm{H}, \\
\mathrm{R}_{2} & =\mathrm{SiMe}_{2} \cdot \mathrm{Bu}^{t} \\
\mathbf{c}: & \mathrm{R}_{1}=\mathrm{D}, \\
\mathrm{R}_{2} & =\mathrm{SiMe}_{2} \cdot \mathrm{Bu}^{t} \\
& \text { Chart } 1
\end{aligned}
$$

$$
\begin{aligned}
7 \mathbf{a}: & \mathrm{R}_{1}=\mathrm{R}_{2}=\mathrm{H} \\
\mathbf{b}: & \mathrm{R}_{1}=\mathrm{H}, \\
& \mathrm{R}_{2}=\mathrm{SiMe}_{2} \cdot \mathrm{Bu}^{t} \\
\mathbf{c}: & \mathrm{R}_{1}=\mathrm{D}, \\
& \mathrm{R}_{2}=\mathrm{SiMe}_{2} \cdot \mathrm{Bu}^{t}
\end{aligned}
$$

12) T. Uwajima, H. Yagi, and O. Terada, Agr. Biol. Chem. (Tokyo), 37, 2345 (1973).

13) T. Nambara, S. Ikegawa, T. Ishizuka, and J. Goto, Chem. Pharm. Bull. (Tokyo), 22, 2656 (1974).

14) T. Nambara, S. Ikegawa, T. Hirayama, and H. Hosoda, Chem. Pharm. Bull. (Tokyo), 25, 3093 (1977). 
that the $\mathrm{A} / \mathrm{B}$-trans fusion is thermodynamically more stable than the $\mathrm{A} / \mathrm{B}$-cis juncture. In actuality the stereochemistry at $\mathrm{C}-5$ retained as judged from the nuclear magnetic resonance (NMR) spectral data. The signal of $3 \alpha$-proton appeared as a doublet of doublets $(J=7,10.5$ $\mathrm{Hz}$ ) at $4.15 \mathrm{ppm}$ and that of 19 -methyl proton at $0.17 \mathrm{ppm}$. Reduction of the oxo group with lithium aluminium hydride did take place along the stereoselective course to form the $4 \beta$-hydroxyl compound (5b) in a satisfactory yield. The product was obviously differentiated from the epimeric $4 \alpha$-hydroxyl compound (3b) and was oxidized back to the 4 -ketone (4). The $\beta$-cis-glycol structure was confirmed by leading to the known $3 \beta, 4 \beta$-diol (5a) by acid hydrolysis. The configuration of the hydroxyl function newly introduced into the C-4 position was thus unambiguously characterized. When $\mathbf{5 b}$ was treated with phosphorous oxychloride in pyridine, dehydration reaction proceeded to the desired direction to yield the $\Delta^{4}$-olefine (2a).

The synthetic route thus established proved to be promising to introduce a deuterium label into the $\mathrm{C}-4$ position of the $\Delta^{4}$-olefine. Reduction of 4 with lithium aluminum deuteride under the conditions described above, followed by resilylation yielded $4 \alpha-d_{1}-5 \alpha$-cholestane$3 \beta, 4 \beta$-diol 3-monosilyl ether (5c). Subsequent dehydration with phosphorus oxychloride in pyridine provided the desired $4-d_{1}$-cholest-4-en-3 $\beta$-ol tert-butyldimethylsilyl ether $(\mathbf{2 b})$. The locality of the heavy isotope at $\mathrm{C}-4$ was justified by the fact that the signal due to $\mathrm{C}-4$ proton disappeared in the NMR spectra.

Treatment of $\mathbf{2 b}$ with $m$-chloroperbenzoic acid in the usual manner yielded the $4 \alpha, 5 \alpha-$ epoxide (6c) together with a trace amount of the $4 \beta, 5 \beta$-epoxide (7c). Reductive cleavage of the oxido ring in $6 \mathbf{c}$ with lithium aluminum hydride furnished the $4 \alpha$-deuterated $5 \alpha$-hydroxyl derivative (8c) as a sole product. Dehydration of $\mathbf{8 c}$ was effected on brief exposure to thionyl chloride in pyridine resulting in formation of the $\Delta^{4}$ - and $\Delta^{5}$-olefines. The mixture was treated with hydrochloric acid and chromatographed on silica gel to provide the desired $4 \alpha-d_{1}$-cholesterol (1a). The mass spectra (MS) and NMR spectra using a shift reagent revealed that these substrates were stereospecifically labeled with deuterium at C-4 or C-6.

The deuterated substrates (1a, $\mathbf{1 b}$ and $\mathbf{1 c}$ ) were incubated with $3 \beta$-hydroxysteroid oxidase under the conditions similar to those described by Uwajima, et al. ${ }^{15)}$ The incubation mixture was extracted with ethyl acetate and the extract was purified by preparative thin-layer chromatography (TLC) to afford cholestenone in $c a .95 \%$ yield. The deuterium content of the biotransformation product was determined by means of mass spectrometry. As listed in Table I the products formed from the $4 \alpha$ - and 6-deuterated substrates (1a and 1c) retained the label almost intact, while that derived from the $4 \beta$-epimer (1) showed a $51 \%$ retention of the isotope.

Inspection of the NMR spectra of the biotransformation products was then performed. The C- 4 proton signal of the product from the $4 \alpha$-deuterated substrate almost disappeared, while those of the products from the $4 \beta$ - and 6 -deuterated compounds were observed as a sharpened singlet and as a doublet $(J=2 \mathrm{~Hz})$, respectively and each signal was equivalent to one proton. Furthermore in the mass spectra of these products two important fragment ion peaks appeared at m/e 343 and 12516) (see Fig. 1). It seemed likely that the heavy isotope of the products formed from the $4 \beta$ - and 6 -deuterated substrates would be located at the $\mathrm{C}-6$ position. It is generally accepted that the infrared (IR) spectrum of a deuterated compound is distinguishable from those of its epimer and the non-deuterated compound. Determination of the isotopic purity by IR spectroscopy was undertaken employing epimeric 6-deuteriocholestenones as authentic specimens. ${ }^{14)}$ Unfortunately the C-D stretching band could not be observed with $6 \beta$ - $d_{1}$-cholestenone. Accordingly, the characteristic bands at 660 and 845 $\mathrm{cm}^{-1}$ for $6 \beta-d_{1}$-cholestenone, at $800 \mathrm{~cm}^{-1}$ for $6 \alpha-d_{1}$-cholestenone, and at 675 and $865 \mathrm{~cm}^{-1}$

15) T. Uwajima, H. Yagi, and O. Terada, Agr. Biol. Chem. (Tokyo), 38, 1149 (1974).

16) R.H. Shapiro and C. Djerassi, J. Am. Chem. Soc., 86, 2825 (1964). 
TABLE I. Results of Deuterium Retention

\begin{tabular}{cccc}
\hline \multirow{2}{*}{ Product } & \multicolumn{3}{c}{ Substrate (\%) } \\
\cline { 2 - 4 } & $4 \alpha-\mathrm{D}(\mathbf{1 a})$ & $4 \beta-\mathrm{D}(\mathbf{1 b})$ & $6-\mathrm{D}(\mathbf{1 c})$ \\
\hline Cholestenone & 98 & 51 & 98 \\
\hline
\end{tabular}

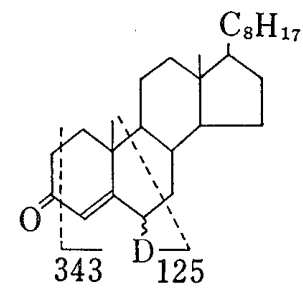

Fig. 1. Mass Fragmentation of 6-Deuterated Cholestenone

for non-labeled cholestenone were used for this purpose. The IR spectrum of the product from 6 -deuterated substrate was entirely identical with that of $6 \alpha-d_{1}$-cholestenone. Comparison of the IR spectrum of the product from the $4 \beta$-deuterated substrate with those of the synthetic mixtures of $6 \beta$-deuterated and non-labeled cholestenones in a variety of ratios was carried out. The spectra in the finger-print region of the biotransformation product and a synthetic mixture of the $6 \beta$-labeled and non-labeled cholestenones $(1: 1)$ were superimposable (Fig. 2). In consequence, it was clarified that the labels retained in the products formed from the $4 \beta$ - and 6-deuterated substrates were located exclusively at the $6 \beta$ - and $6 \alpha$-position, respectively. The present result is fairly consistent with the previous finding that $4 \beta$-hydrogen was transferred directly to the $6 \beta$-position during isomerization of androst-5-ene-3,17-dione into androst-4ene-3,17-dione catalyzed by the pure enzyme from Pseudomonas testosteroni. ${ }^{10}$

It should be pointed out that ca. $50 \%$ of deuterium labeled at the $4 \beta$-position was lost during the course of this biotransformation. A problem whether the loss of the label would proceed under the enzymatic control or non-enzymatic control remained unclear. In order to clarify this point non-labeled and $6 \beta$-deuterated cholestenones were incubated in distilled water or heavy water at $\mathrm{pH} 7.2$ with or without the enzyme. The transformation products were isolated in the manner as described above, and the content and locality of deuterium were determined by inspection of the mass, NMR, and IR spectra. The results obtained are collected in Table II. a

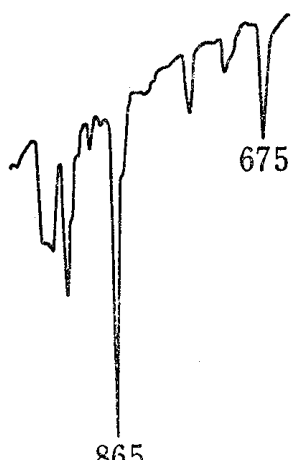

b

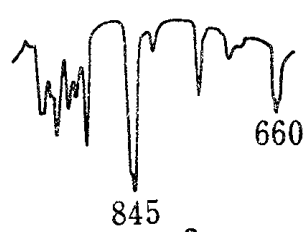

c
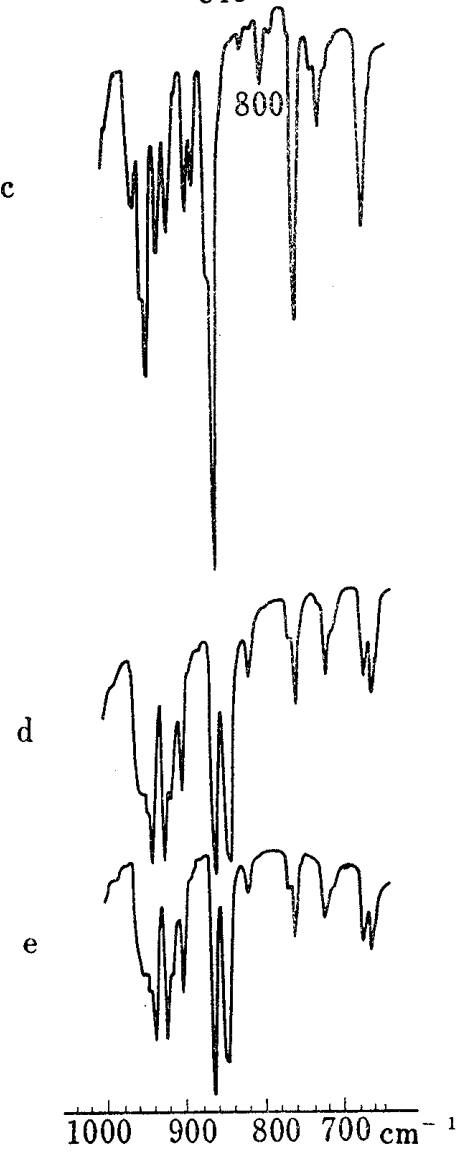

Fig. 2. Infrared Spectra of 6-Deuterated and Non-deuterated Cholestenones

(a) cholestenone; (b) $6 \beta-d_{1}$-cholestenone; (c) $6 a-d_{1}$-cholestenone; (d) mixture of $a$ and $b$ $(1: 1)$; (e) biotransformation product from $4 \beta$ deuterated substrate. 
TABLE II. Results of Deuterium Exchange between Cholestenone and Incubation Medium

\begin{tabular}{clc}
\hline Substrate & \multicolumn{1}{c}{ Condition } & Deuterium content $(\%)$ \\
\hline $6 \beta-D$ & Enzyme control in $\mathrm{H}_{2} \mathrm{O}$ & 72 \\
Non-D & Enzyme control in $\mathrm{D}_{2} \mathrm{O}$ & 41 \\
$6 \beta-D$ & Nonenzyme control in $\mathrm{H}_{2} \mathrm{O}$ & 98 \\
Non-D & Nonenzyme control in $\mathrm{D}_{2} \mathrm{O}$ & 0 \\
\hline
\end{tabular}

When $6 \beta-d_{1}$-cholestenone was conducted in water in the presence of the enzyme, $28 \%$ of labeled deuterium was lost. On the other hand, when the unlabeled substrate was treated in heavy water with the enzyme, deuterium was incorporated into the $6 \beta$-position at a rate of $41 \%$. In the absence of the enzyme, however, any deuterium exchange was not observed with the two substrates irrespective of the incubation medium. This experiment provided an explanation in part for the $c a .50 \%$ loss of deuterium in cholestenone enzymatically produced from $4 \beta-d_{1}$-cholesterol.

These results were led to a definite conclusion that $4 \beta$-hydrogen was transferred stereospecifically to the $6 \beta$-position during transformation of cholesterol into cholestenone by $3 \beta$-hydroxysteroid oxidase. It is generally accepted that conversion of $\Delta^{5}$ - $3 \beta$-hydroxysteroid into $\Delta^{4}$-3-ketosteroid by $3 \beta$-hydroxysteroid oxidase proceeds via the $\Delta^{5}$-3-ketone as an intermediate. The $\Delta^{5} \rightarrow \Delta^{4}$ isomerization may probably involve the stereospecific elimination of $4 \beta$-hydrogen in the $\Delta^{5}$-3-ketosteroid resulting in formation of the $\Delta^{3,5}$-dienol intermediate, followed by protonation at the $6 \beta$-position. Further work in progress in these laboratories will provide the more precise knowledge on the biotransformation mechanism.

\section{Experimenta1 ${ }^{17}$ )}

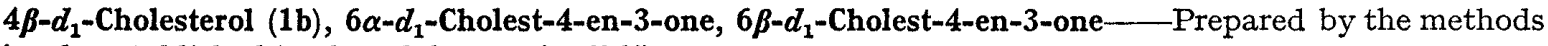
previously established in these laboratories. ${ }^{13,14)}$

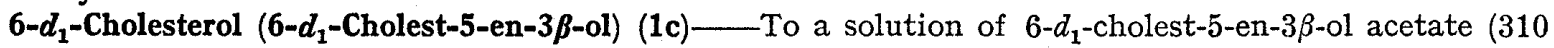
$\mathrm{mg})$ in tetrahydrofuran $(3 \mathrm{ml})-\mathrm{MeOH}(6 \mathrm{ml})$ was added $30 \% \mathrm{KOH}(1 \mathrm{ml})$ and allowed to stand at room temperature for $10 \mathrm{~min}$. The resulting solution was extracted with AcOEt. The organic layer was washed with $\mathrm{H}_{2} \mathrm{O}$, dried over anhydrous $\mathrm{Na}_{2} \mathrm{SO}_{4}$, and evaporated. Recrystallization of the crude product from $\mathrm{MeOH}$ gave 1c $(226 \mathrm{mg})$ as colorless leaflets. $\mathrm{mp} 147.5-148^{\circ}$. IR $v_{\max }^{\mathrm{KBr}} \mathrm{cm}^{-1}: 2240$ (C-D). Mixed melting point on admixture with the non-labeled authentic sample showed no depression. MS $m / e: 387\left(\mathrm{M}^{+}\right)\left(98 \% d_{1}\right)$.

$5 \alpha$-Cholestane-3 $\beta, 4 \alpha$-diol 3-tert-Butyldimethylsilyl Ether (3b)-To a stirred solution of cholest-4-en$3 \beta$-ol tert-butyldimethylsilyl ether $\left.(2 \mathrm{a})^{18}\right)(300 \mathrm{mg})$ and $\mathrm{LiAlH}_{4}(360 \mathrm{mg})$ in anhydrous ether $(18 \mathrm{ml})$ was added $\mathrm{BF}_{3}$-etherate $(3 \mathrm{~g})$ in anhydrous ether $(18 \mathrm{ml})$ at $0^{\circ}$ over a period of 15 min under a stream of $\mathrm{N}_{2}$ gas and stirred at room temperature for $1 \mathrm{hr}$. After addition of moist ether the resulting solution was extracted with ether. The organic layer was washed with $5 \% \mathrm{NaHCO}_{3}$ and $\mathrm{H}_{2} \mathrm{O}$, dried over anhydrous $\mathrm{Na}_{2} \mathrm{SO}_{4}$, and evaporated. To a solution of this residue in tetrahydrofuran $(10 \mathrm{ml})$ were added dropwise $10 \% \mathrm{NaOH}(4 \mathrm{ml})$ and $30 \% \mathrm{H}_{2} \mathrm{O}_{2}(3 \mathrm{ml})$ under ice-cooling and stirred at $0^{\circ}$ for $1 \mathrm{hr}$. The resulting solution was diluted with $\mathrm{H}_{2} \mathrm{O}$ and extracted with ether. The organic layer was washed with $5 \% \mathrm{NaHSO}_{3}, 5 \% \mathrm{NaHCO}_{3}$, and $\mathrm{H}_{2} \mathrm{O}$, successively, dried over anhydrous $\mathrm{Na}_{2} \mathrm{SO}_{4}$, and evaporated. The crude product was purified by preparative TLC using hexane-AcOEt (100:1) as developing solvent. Recrystallization of the eluate from ether-MeOH gave $3 \mathrm{~b}(210 \mathrm{mg})$ as colorless leaflets. $\mathrm{mp} 197-198^{\circ}$. $[\alpha]_{\mathrm{D}}^{22}+20.0^{\circ}(c=0.20)$. Anal. Calcd. for $\mathrm{C}_{33} \mathrm{H}_{62} \mathrm{O}_{2} \mathrm{Si}$ : $\mathrm{C}$, 76.38; H, 12.04. Found: C, 76.28; H, 12.08. NMR $\left(\mathrm{CDCl}_{3}\right) \delta: 0.08\left(6 \mathrm{H}, \mathrm{s}, \mathrm{Si}\left(\mathrm{CH}_{3}\right)_{2}\right), 0.64(3 \mathrm{H}, \mathrm{s}, 18-$ $\left.\mathrm{CH}_{3}\right), 0.90\left(9 \mathrm{H}, \mathrm{s}, t-\mathrm{C}_{4} \mathrm{H}_{9}\right), 3.1-3.5(2 \mathrm{H}, \mathrm{m}, 3 \alpha-$ and $4 \beta-\mathrm{H})$.

17) All melting points were taken on a micro hot-stage apparatus and are uncorrected. Optical rotations were measured in $\mathrm{CHCl}_{3}$. Infrared (IR) spectral measurements were run on a JASCO Model IRA-1 spectrometer. Mass spectra were obtained on a Hitachi Model RMU-7 spectrometer. Nuclear magnetic resonance (NMR) spectra were recorded on a JEOL Model PS-100 spectrometer at $100 \mathrm{MHz}$ using tetramethylsilane as an internal standard. Abbreviation used $\mathrm{s}=$ singlet, $\mathrm{d}=$ doublet, dd=doublet of doublets, and $\mathrm{m}=$ multiplet. The shift reagent was stored in vacuo over $\mathrm{P}_{2} \mathrm{O}_{5}$ until the use. Abbreviation used $\mathrm{Eu}(\text { fod })_{3}=\operatorname{tris}(1,1,1,2,2,3,3$-heptafluoro-7,7-dimethyl-4,6-octanedionate)europium (III). For preparative TLC silica gel $\mathrm{H}$ and silica gel $\mathrm{HF}_{254}$ (E. Merck AG, Darmstadt) were used as adsorbents.

18) H. Hosoda, K. Yamashita, H. Sagae, and T. Nambara, Chem. Pharm. Bull. (Tokyo), 23, 2118 (1975). 
Hydrolysis of $3 \mathrm{~b}$ - To a solution of $3 \mathbf{b}(5 \mathrm{mg})$ in acetone $(5 \mathrm{ml})$ was added $5 \mathrm{~N} \mathrm{HCl}(0.05 \mathrm{ml})$ and allowed to stand at $60^{\circ}$ for $30 \mathrm{~min}$. The resulting solution was neutralized with $5 \% \mathrm{NaHCO}_{3}$, concentrated to its half volume under the reduced pressure, and extracted with ether. The organic layer was washed with $\mathrm{H}_{2} \mathrm{O}$, dried over anhydrous $\mathrm{Na}_{2} \mathrm{SO}_{4}$, and evaporated. The crude product obtained was purified by preparative TLC using hexane-AcOEt $(4: 1)$ as developing solvent. Recrystallization of the eluate from MeOH gave $5 \alpha$-cholestane-3 $\beta, 4 \alpha$-diol (3a) $\left(3 \mathrm{mg}\right.$ ) as colorless leaflets. mp $232-234^{\circ}$ (reported $\mathrm{mp} 236-238^{\circ}$ ). ${ }^{19}$ )

$3 \beta$-Hydroxy-5 $\alpha$-cholestan-4-one tert-Butyldimethylsilyl Ether (4)__. To a solution of AcONa (75 mg) and pyridinium chlorochromate $(1 \mathrm{~g})$ in anhydrous $\mathrm{CH}_{2} \mathrm{Cl}_{2}(5 \mathrm{ml})$ was added $3 \mathrm{~b}(500 \mathrm{mg})$ in anhydrous $\mathrm{CH}_{2} \mathrm{Cl}_{2}$ $(5 \mathrm{ml})$ and stirred at room temperature for $14 \mathrm{hr}$. After addition of anhydrous ether the resulting solution was passed through a short pad of alumina. The organic layer was combined and evaporated. Recrystallization of the crude product from ether-MeOH gave $4(400 \mathrm{mg})$ as colorless leaflets. $\mathrm{mp} 135-138^{\circ} . \quad[\alpha]_{\mathrm{D}}^{21}+1.9^{\circ}$ $(c=0.27)$. Anal. Calcd. for $\mathrm{C}_{33} \mathrm{H}_{60} \mathrm{O}_{2} \mathrm{Si}: \mathrm{C}, 76.68 ; \mathrm{H}, 11.70$. Found: C, 76.48; H, 11.89. NMR $\left(\mathrm{CDCl}_{3}\right) \delta$ : $0.12\left(6 \mathrm{H}, \mathrm{s}, \mathrm{Si}\left(\mathrm{CH}_{3}\right)_{2}\right), 0.64\left(3 \mathrm{H}, \mathrm{s}, 18-\mathrm{CH}_{3}\right), 0.71\left(3 \mathrm{H}, \mathrm{s}, 19-\mathrm{CH}_{3}\right), 0.89\left(9 \mathrm{H}, \mathrm{s}, t-\mathrm{C}_{4} \mathrm{H}_{9}\right), 4.15(1 \mathrm{H}, \mathrm{dd}, J=7$, $10.5 \mathrm{~Hz}, 3 \alpha-\mathrm{H})$.

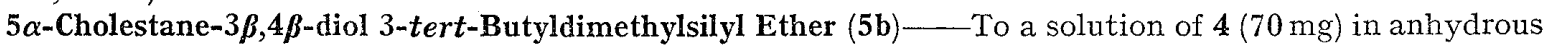
ether $(5 \mathrm{ml})$ was added $\mathrm{LiAlH}_{4}(30 \mathrm{mg})$ and stirred at room temperature for $40 \mathrm{~min}$. After addition of moist ether and $20 \%$ Rochelle salt solution the resulting solution was extracted with ether. The organic layer was washed with $\mathrm{H}_{2} \mathrm{O}$, dried over anhydrous $\mathrm{Na}_{2} \mathrm{SO}_{4}$, and evaporated. The residue was treated with tert-butyldimethylsilyl chloride $(200 \mathrm{mg})$ and imidazole $(400 \mathrm{mg})$ in dimethylformamide (DMF) (2 ml)-pyridine $(1 \mathrm{ml})$ at room temperature for $3 \mathrm{hr}$. The reaction mixture was diluted with $\mathrm{H}_{2} \mathrm{O}$ and extracted with ether. The organic layer was washed with $\mathrm{H}_{2} \mathrm{O}$, dried over anhydrous $\mathrm{Na}_{2} \mathrm{SO}_{4}$, and evaporated. The crude product was purified by preparative TLC using hexane-benzene (2:1) as developing solvent. Recrystallization of

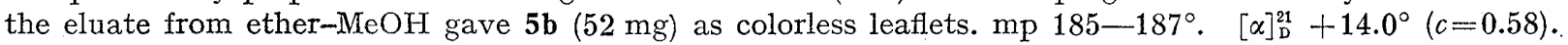
Anal. Calcd. for $\mathrm{C}_{33} \mathrm{H}_{62} \mathrm{O}_{2} \mathrm{Si} \cdot 1 / 2 \mathrm{H}_{2} \mathrm{O}: \mathrm{C}, 75.08 ; \mathrm{H}, 12.03$. Found: C, 74.65; H, 11.65. NMR $\left(\mathrm{CDCl}_{3}\right) \delta$ : $0.06\left(6 \mathrm{H}, \mathrm{s}, \mathrm{Si}\left(\mathrm{CH}_{3}\right)_{2}\right), 0.64\left(3 \mathrm{H}, \mathrm{s}, 18-\mathrm{CH}_{3}\right), 0.89\left(9 \mathrm{H}, \mathrm{s}, t-\mathrm{C}_{4} \mathrm{H}_{9}\right), 1.03\left(3 \mathrm{H}, \mathrm{s}, 19-\mathrm{CH}_{3}\right), 3.40-3.72(2 \mathrm{H}, \mathrm{m}, 3 \alpha-$ and $4 \alpha-\mathrm{H})$.

Oxidation of $\mathbf{5 b}$ with $\mathrm{CrO}_{3}$-pyridine Complex-To a solution of $\mathbf{5 b}(30 \mathrm{mg})$ in pyridine $(1 \mathrm{ml})$ was added $\mathrm{CrO}_{3}$-pyridine complex $(1: 10 \mathrm{w} / \mathrm{v})(1 \mathrm{ml})$ and stirred at room temperature for $5 \mathrm{hr}$. The reaction mixture was diluted with ether, washed with $10 \% \mathrm{AcOH}, 5 \% \mathrm{NaHCO}_{3}$, and $\mathrm{H}_{2} \mathrm{O}$, successively, and dried over anhydrous $\mathrm{Na}_{2} \mathrm{SO}_{4}$. After usual work-up the crude product was purified by preparative TLC using hexanebenzene $(2: 1)$ as developing solvent. Recrystallization of the eluate from ether-MeOH gave $4(22 \mathrm{mg})$ as colorless leaflets. mp 128.5-130 . Mixed melting point on admixture with the authentic sample showed no depression.

Hydrolysis of $5 \mathbf{b}$ _- Treatment of $5 \mathbf{b}(10 \mathrm{mg})$ in $\mathrm{MeOH}$ with $5 \mathrm{~N} \mathrm{HCl}$ was carried out in the manner as described with $3 \mathrm{~b}$. Recrystallization of the crude product from MeOH gave $5 \alpha$-cholestane-3 $\beta$, $4 \beta$-diol (5a) $\left(7 \mathrm{mg}\right.$ ) as colorless needles. $\mathrm{mp} 198-201^{\circ}$ (reported $\left.\mathrm{mp} 199-201^{\circ}\right) .^{20}$ )

Dehydration of $\mathbf{5 b} \mathbf{b} \ldots$ To a solution of $\mathbf{5 b}(10 \mathrm{mg})$ in pyridine $(1 \mathrm{ml})$ was added $\mathrm{POCl}_{3}(0.2 \mathrm{ml})$ under ice-cooling and stirred at room temperature overnight. After addition of moist ether the resulting solution was extracted with ether. The organic layer was washed with $5 \% \mathrm{NaHCO}_{3}$ and $\mathrm{H}_{2} \mathrm{O}$, dried over anhydrous $\mathrm{Na}_{2} \mathrm{SO}_{4}$, and evaporated. The crude product was purified by preparative TLC using hexane as developing solvent. Recrystallization of the eluate from ether- $\mathrm{MeOH}$ gave $2 \mathrm{a}(6 \mathrm{mg})$ as colorless leaflets. $\mathrm{mp} 111-112^{\circ}$. Mixed melting point on admixture with the authentic sample showed no depression.

$4 \alpha-d_{1}-5 \alpha$-Cholestane-3 $\beta, 4 \beta$-diol 3-tert-Butyldimethylsilyl Ether (5c)-To a solution of 4 (1.4 g) in anhydrous ether $(30 \mathrm{ml})$ was added $\mathrm{LiAlD}_{4}(600 \mathrm{mg})$ and stirred at room temperature for 30 min. After addition of moist ether and $20 \%$ Rochelle salt solution the resulting solution was extracted with ether. The organic layer was washed with $\mathrm{H}_{2} \mathrm{O}$, dried over anhydrous $\mathrm{Na}_{2} \mathrm{SO}_{4}$, and evaporated. The residue obtained was treated with tert-butyldimethylsilyl chloride $(2.2 \mathrm{~g})$ and imidazole $(4.5 \mathrm{~g})$ in DMF $(8 \mathrm{ml})$-pyridine $(4 \mathrm{ml})$ at room temperature for $3 \mathrm{hr}$. The reaction mixture was diluted with $\mathrm{H}_{2} \mathrm{O}$ and extracted with ether. The organic layer was washed with $\mathrm{H}_{2} \mathrm{O}$, dried over anhydrous $\mathrm{Na}_{2} \mathrm{SO}_{4}$, and evaporated. The crude product was submitted to column chromatography on silica gel. Elution with hexane-benzene (2: 1) gave a crystalline product $(1.25 \mathrm{~g})$ which was submitted to further elaboration without purification. A portion of the eluate was recrystallized from ether-MeOH to give $5 \mathrm{c}$ as colorless leaflets. mp $193-194^{\circ}$. Mixed melting point on admixture with the non-labeled authentic sample (5b) showed no depression.

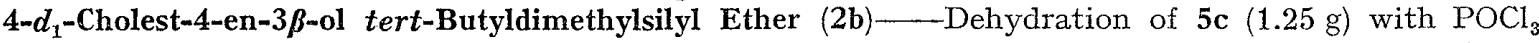
in pyridine was carried out in the manner as described with $\mathbf{5 b}$. The crude product was submitted to column chromatography on silica gel. Elution with hexane-AcOEt $(50: 1)$ gave a crystalline product $(1 \mathrm{~g})$ which was submitted to further elaboration without purification. A portion of the eluate was recrystallized from ether-MeOH to give $\mathbf{2 b}$ as colorless leaflets. mp 111-114 ${ }^{\circ}$. Mixed melting point on admixture with the nonlabeled authentic sample (2a) showed no depression. NMR $\left(\mathrm{CDCl}_{3}\right) \delta: 0.08\left(6 \mathrm{H}, \mathrm{s}, \mathrm{Si}\left(\mathrm{CH}_{3}\right)_{2}\right), 0.67(3 \mathrm{H}, \mathrm{s}$, $\left.18-\mathrm{CH}_{3}\right), 0.89\left(9 \mathrm{H}, \mathrm{s}, t-\mathrm{C}_{4} \mathrm{H}_{9}\right), 1.03\left(3 \mathrm{H}, \mathrm{s}, 19-\mathrm{CH}_{3}\right), 4.20(1 \mathrm{H}, \mathrm{m}, 3 \alpha-\mathrm{H})$.

19) M. Nussim, Y. Mazur, and F. Sondheimer, J. Org. Chem., 29, 1120 (1964).

20) S.M. Kupchan, P. Slade, R.J. Young, and G.W.A. Milne, Tetrahedron, 18, 499 (1962). 


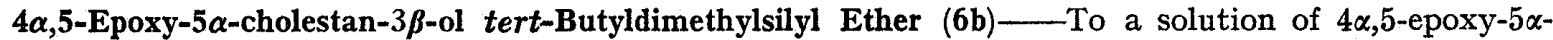
cholestan-3 $\beta$-ol $\left.(6 \mathrm{a})^{13}\right)(40 \mathrm{mg})$ in DMF $(0.5 \mathrm{ml})$-pyridine $(0.2 \mathrm{ml})$ were added imidazole $(200 \mathrm{mg})$ and tertbutyldimethylsilyl chloride $(100 \mathrm{mg})$ and allowed to stand at room temperature for $10 \mathrm{~min}$. The resulting solution was diluted with ether, washed with $\mathrm{H}_{2} \mathrm{O}$, dried over anhydrous $\mathrm{Na}_{2} \mathrm{SO}_{4}$, and evaporated. Recrystallization of the crude product from ether-MeOH gave $6 \mathrm{~b}(45 \mathrm{mg})$ as colorless leaflets. $\mathrm{mp} 176.5-178^{\circ}$. $[\alpha]_{\mathrm{D}}^{13}+50.0^{\circ}(c=0.38)$. Anal. Calcd. for $\mathrm{C}_{33} \mathrm{H}_{60} \mathrm{O}_{2} \mathrm{Si}: \mathrm{C}, 76.68 ; \mathrm{H}, 11.70$. Found: $\mathrm{C}, 76.62 ; \mathrm{H}, 11.84$. NMR $\left(\mathrm{CDCl}_{3}\right) \delta: 0.08\left(6 \mathrm{H}, \mathrm{s}, \mathrm{Si}\left(\mathrm{CH}_{3}\right)_{2}\right), 0.67\left(3 \mathrm{H}, \mathrm{s}, 18-\mathrm{CH}_{3}\right), 0.89\left(9 \mathrm{H}, \mathrm{s}, t-\mathrm{C}_{4} \mathrm{H}_{9}\right), 1.08\left(3 \mathrm{H}, \mathrm{s}, 19-\mathrm{CH}_{3}\right), 2.82(1 \mathrm{H}, \mathrm{s}$, $4 \beta-\mathrm{H}), 3.90(1 \mathrm{H}, \mathrm{m}, 3 \alpha-\mathrm{H})$.

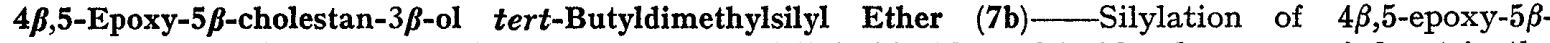
cholestan-3 $\beta$-ol $\left.(7 \mathrm{a})^{21}\right)(30 \mathrm{mg})$ with tert-butyldimethylsilyl chloride and imidazole was carried out in the manner as described with $6 \mathbf{a}$. Recrystallization from MeOH gave $\mathbf{7 b}(33 \mathrm{mg}$ ) as colorless needles. mp $89-$ 89.5 ${ }^{\circ}[\alpha]_{\mathrm{D}}^{18}+1.5^{\circ}(c=0.49)$. Anal. Calcd. for $\mathrm{C}_{33} \mathrm{H}_{60} \mathrm{O}_{2} \mathrm{Si}: \mathrm{C}, 76.68 ; \mathrm{H}, 11.70$. Found: $\mathrm{C}, 76.46 ; \mathrm{H}$, 11.89. NMR $\left(\mathrm{CDCl}_{3}\right) \delta: 0.05,0.06$ (each $\left.3 \mathrm{H}, \mathrm{s}, \mathrm{Si}\left(\mathrm{CH}_{3}\right)_{2}\right), 0.70\left(3 \mathrm{H}, \mathrm{s}, 18-\mathrm{CH}_{3}\right), 0.96\left(9 \mathrm{H}, \mathrm{s}, t-\mathrm{C}_{4} \mathrm{H}_{9}\right), 1.07$ $\left(3 \mathrm{H}, \mathrm{s}, 19-\mathrm{CH}_{3}\right), 3.01(1 \mathrm{H}, \mathrm{d}, J=3 \mathrm{~Hz}, 4 \alpha-\mathrm{H}), 4.08(1 \mathrm{H}, \mathrm{m}, 3 \alpha-\mathrm{H})$.

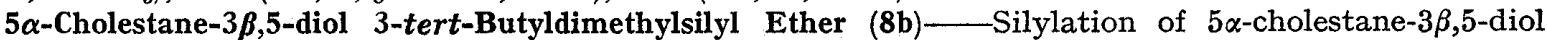
$\left.(8)^{13}\right)(100 \mathrm{mg})$ with tert-butyldimethylsilyl chloride and imidazole was carried out in the manner as described with 6a. Recrystallization from ether-MeOH gave $8 \mathrm{~b}(114 \mathrm{mg})$ as colorless needles. $\mathrm{mp} 186-188^{\circ}$. [ $\left.\alpha\right]_{\mathrm{D}}^{21}$ $-11.9^{\circ}(c=0.21)$. Anal. Calcd. for $\mathrm{C}_{33} \mathrm{H}_{62} \mathrm{O}_{2} \mathrm{Si}: \mathrm{C}, 76.68 ; \mathrm{H}, 11.70$. Found: $\mathrm{C}, 76.35 ; \mathrm{H}, 12.10$. NMR $\left(\mathrm{CDCl}_{3}\right) \delta: 0.04\left(6 \mathrm{H}, \mathrm{s}, \mathrm{Si}\left(\mathrm{CH}_{3}\right)_{2}\right), 0.64\left(3 \mathrm{H}, \mathrm{s}, 18-\mathrm{CH}_{3}\right), 0.89\left(9 \mathrm{H}, \mathrm{s}, t-\mathrm{C}_{4} \mathrm{H}_{9}\right), 0.99\left(3 \mathrm{H}, \mathrm{s}, 19-\mathrm{CH}_{3}\right), 4.08(1 \mathrm{H}$, $\mathrm{m}, 3 \alpha-\mathrm{H})$.

Epoxidation of $2 \mathrm{~b}$ - To a solution of $2 \mathrm{~b}(1 \mathrm{~g})$ in benzene $(20 \mathrm{ml})$ was added $m$-chloroperbenzoic acid $(500 \mathrm{mg})$ and stirred at room temperature for $1.5 \mathrm{hr}$. The reaction mixture was diluted with ether, washed with $5 \% \mathrm{NaHSO}_{3}, 5 \% \mathrm{NaHCO}_{3}$, and $\mathrm{H}_{2} \mathrm{O}$, successively, dried over anhydrous $\mathrm{Na}_{2} \mathrm{SO}_{4}$, and evaporated. The crude product was submitted to column chromatography on silica gel. Elution with hexane-benzene (3:1) and recrystallization of the less polar eluate from ether-MeOH gave $4 \beta-d_{1}-4 \alpha, 5$-epoxy-5 $\alpha$-cholestan$3 \beta$-ol tert-butyldimethylsilyl ether $(6 \mathrm{c})(845 \mathrm{mg})$ as colorless leaflets. mp $176-177^{\circ}$. Mixed melting point on admixture with the non-labeled authentic sample $(\mathbf{6 b})$ showed no depression. Recrystallization of the more polar eluate from $\mathrm{MeOH}$ gave $4 \alpha-d_{1}-4 \beta, 5$-epoxy-5 $\beta$-cholestan-3 $\beta$-ol tert-butyldimethylsilyl ether (7c) $(52 \mathrm{mg})$ as colorless leaflets. mp $88-89^{\circ}$. Mixed melting point on admixture with the non-labeled authentic sample (7b) showed no depression.

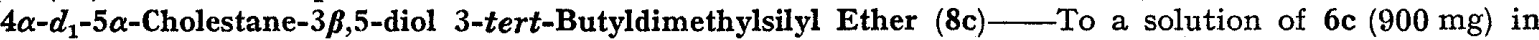
anhydrous ether $(30 \mathrm{ml})$ was added $\mathrm{LiAlH}_{4}(700 \mathrm{mg})$ and refluxed for $30 \mathrm{hr}$. After addition of moist ether and $20 \%$ Rochelle salt solution the resulting solution was extracted with ether. The organic layer was washed with $\mathrm{H}_{2} \mathrm{O}$, dried over anhydrous $\mathrm{Na}_{2} \mathrm{SO}_{4}$, and evaporated. The crude product (820 mg) was submitted to further elaboration without purification. A portion of the crude product was recrystallized from $\mathrm{MeOH}$ to give 8c as colorless needles. $\mathrm{mp} 186-188^{\circ}$. Mixed melting point on admixture with the non-labeled authentic sample (8b) showed no depression.

$4 \alpha-d_{1}$-Cholesterol (1a)_- To a solution of $8 \mathrm{c}(820 \mathrm{mg})$ in pyridine $(10 \mathrm{ml})$ was added $\mathrm{SOCl}_{2}(0.8 \mathrm{ml})$ in $\mathrm{CHCl}_{3}(0.8 \mathrm{ml})$ under ice-cooling and stirred at $0^{\circ}$ for $5 \mathrm{~min}$. After addition of moist ether the resulting solution was extracted with ether. The organic layer was washed with $5 \% \mathrm{NaHCO}_{3}$ and $\mathrm{H}_{2} \mathrm{O}$, dried over anhydrous $\mathrm{Na}_{2} \mathrm{SO}_{4}$, and evaporated. The residue obtained was treated with $6 \mathrm{~N} \mathrm{HCl}(2 \mathrm{ml})$ in acetone $(10 \mathrm{ml})$-ether $(10 \mathrm{ml})$ at $60^{\circ}$ for $30 \mathrm{~min}$. The resulting solution was neutralized with $5 \% \mathrm{NaHCO}_{3}$, concentraed to its half volume under the reduced pressure, and extracted with AcOEt. The organic layer was washed with $\mathrm{H}_{2} \mathrm{O}$, dried over anhydrous $\mathrm{Na}_{2} \mathrm{SO}_{4}$, and evaporated. The crude product was purified by column chromatography on silica gel. Elution with hexane-AcOEt $(10: 1)$ and recrystallization of the eluate from MeOH gave $1 \mathrm{a}(234 \mathrm{mg})$ as colorless leaflets. $\mathrm{mp} 145-146.5^{\circ}$. IR $\nu_{\max }^{\mathrm{KBr}} \mathrm{cm}^{-1}: 2175$. Mixed melting point on admixture with the non-labeled authentic sample showed no depression. MS m/e: $387\left(\mathrm{M}^{+}\right)\left(98 \% d_{1}\right)$.

NMR Spectra of Substrates-_-NMR spectra of non-labeled and deuterated cholesterols (1a, 1b and 1c) with $0.21 \mathrm{~mol}$ equivalent each of $\mathrm{Eu}(\mathrm{fod})_{3}$ in $\mathrm{CCl}_{4}$ were measured at $28^{\circ}$. The $\mathrm{C}-4$ and $\mathrm{C}-6$ proton signals in the NMR spectra were assigned as follows:

\begin{tabular}{|c|c|c|c|}
\hline \multirow{2}{*}{ Compound } & \multicolumn{3}{|c|}{ Chemical shift $(\delta)$ ppm } \\
\hline & $4 \alpha-\mathrm{H}$ & $4 \beta-\mathrm{H}$ & $6-\mathrm{H}$ \\
\hline Cholesterol & $5.24, \mathrm{~m}$ & $5.48, \mathrm{~m}$ & $\begin{array}{l}5.90, \text { broad d } \\
J=4 \mathrm{~Hz}\end{array}$ \\
\hline $4 \alpha-D(1 a)$ & & $5.74, \mathrm{~m}$ & 5.96 , broad s \\
\hline $4 \beta-D(1 b)$ & $5.14, \mathrm{~m}$ & & $\begin{array}{l}5.92, \text { broad d } \\
J=4 \mathrm{~Hz}\end{array}$ \\
\hline $6-\mathrm{D}(1 \mathrm{c})$ & $5.38, \mathrm{~m}$ & $5.68, \mathrm{~m}$ & \\
\hline
\end{tabular}

21) D.J. Collins, Aust. J. Chem., 16, 658 (1963). 
Incubation Study_-To a solution of deuterated cholesterol (1a, 1b or 1c) (ca. $20 \mathrm{mg})$ in $95 \%$ EtOH $(0.2 \mathrm{ml})$ was added cholesterol oxidase (Kyowa Hakko Kogyo Co., Ltd.) (4 mg) in $0.03 \mathrm{~m}$ phosphate buffer $(\mathrm{pH} 7.2)(60 \mathrm{ml})$ and incubated at $37^{\circ}$ for $21 \mathrm{hr}$. The incubation mixture was extracted with AcOEt. The organic layer was washed with $\mathrm{H}_{2} \mathrm{O}$, dried over anhydrous $\mathrm{Na}_{2} \mathrm{SO}_{4}$, and evaporated. The crude product was purified by preparative TLC using hexane-AcOEt $(5: 1)$ as developing solvent. Recrystallization of the eluate from MeOH gave cholestenone as colorless plates in $c a .95 \%$ yield. The deuterium content of cholestenone formed from each substrate was determined by inspection of the molecular ion peak in the mass spectra (Table I). The C-4 proton signals of cholestenone in the NMR spectra were assigned as follows:

\begin{tabular}{cccc}
\hline Product & \multicolumn{3}{c}{ Substrate } \\
& $4 \alpha-\mathrm{D}$ & $4 \beta-\mathrm{D}$ & $6-\mathrm{D}$ \\
\hline \multirow{2}{*}{ Cholestenone } & Disappeared & 5.76 & $5.76 \mathrm{ppm}$ \\
& $\mathrm{s}, W 1 / 2=1.5 \mathrm{~Hz}$ & $\mathrm{~d}, J=2 \mathrm{~Hz}$ \\
\hline
\end{tabular}

Deuterium Exchange between Cholestenone and Incubation Medium_-Cholestenone and $6 \beta-d_{1}$-cholestenone were incubated at $37^{\circ}$ for $21 \mathrm{hr}$ under the following conditions:

\begin{tabular}{lccccc}
\hline \multicolumn{2}{c}{ Cholestenone } & \multicolumn{2}{c}{ EtOH } \\
& $\mathrm{mg}$ & $\mathrm{ml}$ & $\begin{array}{c}\text { Enzyme } \\
\mathrm{mg}\end{array}$ & \multicolumn{2}{c}{ Medium } \\
& & & & $\mathrm{ml}$ \\
\hline $6 \beta$-D & 4.4 & $0.2^{(a)}$ & 2 & $\mathrm{H}_{2} \mathrm{O}$ & 5 \\
Non-D & 5.6 & $0.2^{b)}$ & 2 & $\mathrm{D}_{2} \mathrm{O}$ & 5 \\
$6 \beta$-D & 5.1 & $0.2^{a)}$ & None & $\mathrm{H}_{2} \mathrm{O}$ & 5 \\
Non-D & 5.7 & $0.2^{b)}$ & None & $\mathrm{D}_{2} \mathrm{O}$ & 5 \\
\hline
\end{tabular}

Enzyme: cholesterol oxidase, $\mathrm{H}_{2} \mathrm{O}: 0.03$ м phosphate buffer $(\mathrm{pH} 7.2), \mathrm{D}_{2} \mathrm{O}: 0.03 \mathrm{M}$ phosphate buffer in $\mathrm{D}_{2} \mathrm{O}$ ( $\mathrm{pH} 7.2$ ).

a) $99 \%$ EtOH $\quad$ b) $95 \% \mathrm{EtOH}$

Isolation of cholestenone from the incubation mixture was carried out in the manner as described above. The deuterium content was determined by inspection of the molecular ion peak in the mass spectra (Table II).

Acknowledgement The authors are indebted to all the staff of central analytical laboratory of this Institute for elemental analyses and spectral measurements. This work was supported in part by a Grantin-Aid for Scientific Research from the Ministry of Education, Science and Culture, which is gratefully acknowledged. They express their sincere thanks to Kyowa Hakko Kogyo Co., Ltd. for generous supply of cholesterol oxidase. 